\title{
The potential impact of marine protected areas on the Senegalese sardinella fishery
}

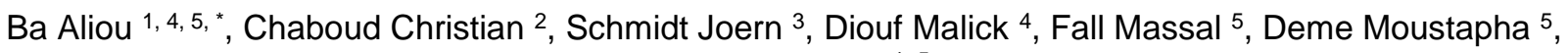
Brehmer Patrice ${ }^{1,5}$

1 Inst Rech Dev France IRD, UMR Lemar, BP 1386, Dakar, Senegal.

2 Inst Rech Dev France IRD, UMR Marbec, Sete, Senegal.

3 Univ Kiel CAU, Dept Econ, Wilhelm Seelig PI 1, D-24118 Kiel, Germany.

4 UCAD, Inst Univ Peche \& Aquaculture, UCAD 2,BP 45784, Dakar, Senegal.

${ }^{5}$ ISRA, CRODT, Ctr PRH, BP 2241, Dakar, Senegal.

* Corresponding author : Aliou Ba, email address : aliouba81@gmail.com

\begin{abstract}
:
In the early 2000s, Senegal set up several Marine Protected Areas (MPAs) along its coastal zone with the purpose of biodiversity conservation and to support sustainable management of fisheries. However, the impact of MPAs may vary according to the type of fisheries. In Senegal, the sardinella fishery accounts for $70 \%$ of total catches. This fishery is of crucial importance for national food security and employment. Given this importance, it is necessary to evaluate the impact of MPAs, often being considered as a tool for fisheries management. An analytical, dynamic and spatial bio-economic model of sardinella fishery, considering fish and fisher migration, has been developed and scenarios over forty years have been analyzed. The results show that the fishery is economically overexploited and that Senegal could lose about 11.6 billion CFA over forty years of exploitation, i.e. 290 million CFA per year. To achieve an optimal level of exploitation, it would be necessary to halve the current fishing capacity. Implementing MPAs for 10,20 and $30 \%$ of the Senegalese exclusive economic zone lead to slight increases in biomass (1\%) and rent $(5-11 \%)$. In addition, spatio-temporal closures can lead to increased exploitation in unclosed areas, due to the absence of enforcement. Achieving target 11 of the Aichi Convention, i.e., $10 \%$ of coastal and marine areas protected per country, will have a reserve effect on the resource but also only lead to weak improvements in economic indicators for the Senegalese fishery. Finally, because the sardinella resource is shared among many countries of the Sub-Regional Fisheries Commission (SRFC), a sub-regional cooperation is necessary for a sustainable management.
\end{abstract}




\section{Highlights}

- The Sardinella fishery is economically overexploited and that the society loses about 290 million CFA per year. To reach an optimal level of exploitation, the current fishing capacity should be halved. Spatio-temporal closure measures or MPAs lead inevitably to overcapacity in unclosed areas. The objective 11 of the Aichi Convention will have a reserve effect on the resource.

Keywords : Small scale fisheries, MPA, Bioeconomic modeling, Fishing capacity, Fishery management, Sardinella aurita, Sardinella maderensis, Aichi targets, West Africa 


\section{INTRODUCTION}

The exploitation of sardinella (Sardinella aurita and Sardinella maderensis) has a long tradition in Senegal. It expanded with the development of the artisanal purse seine fishery in the 1970s, following an investment into the sector by an FAO project (Dème and Kébé, 2000). Today sardinella catches represent $70 \%$ of the total catch of the Senegalese artisanal fishery in volume (Thiaw et al., 2017) and contribute mainly to the supply of the local and regional market (Dème et al., 2012; Ba, 2017; Ba et al., 2017). Sardinella fisheries play a dual role in the Senegalese economy. Through its contributions to food security and employment, it employs more than $25 \%$ of artisanal fishers (16 000 fishers) and provides about $70 \%$ of Senegal's fish consumption (Ba, 2017).

The sustainability of this fishery is facing many challenges. The overexploitation of the stocks of small pelagic fish is the main one (FAO, 2015; Baldé et al. 2018). In Senegal, the fishery on small pelagics is mainly artisanal, open access and subsidized. Other types of exploitation may compete with artisanal fishing and increased pressure on the resource. These include foreign industrial fishing and national industrial small pelagic fishing. Recently, demand has increased with the establishment of fishmeal industries but also with the opening of new export markets in the sub-region. This situation inexorably contributes to the increase in fishing effort in the area ((Diankha et al., 2018). Sardinella stocks migrate between different EEZs (Exclusive Economic Zone) and are shared between Senegal and its neighboring countries (Morocco, Mauritania, Gambia and Guinea-Bissau). Fishing activity for each of the countries therefore depends on the level of exploitation in other countries. In recent years the exploitation of sardinella has intensified in the neighboring areas of Senegal, due to foreign investment for the development of the national fishing or even the presence of international fleets, mainly Dutch and Russian (Corten et al., 2012). According to the FAO, (2017) 2016 landings in countries sharing the resource is around 125552 tonnes for Senegal, 91013 tonnes for Mauritania and 6929 tonnes for Gambia. This also reflects the intensity of the fishing effort in the area. 
In parallel with this dynamics, Senegal signed the International Convention on Biological Diversity in 1992 (Anonymous, 1992) and aims to achieve the Aichi biodiversity targets relating to the strategic plan for biodiversity on a global scale for the period 2011-2020. Aichi target 11 calls for a protection of at least $10 \%$ of the coastal zone by 2020 (Anonymous, 2014; Thomas et al., 2014). Senegal is committed to setting up a network of marine protected areas to preserve marine and coastal biodiversity, but also to ensure sustainable development of fisheries (Anonymous, 2013). Since the beginning of the 2000s, several coastal MPAs have been created, such as off Saint-Louis $\left(496 \mathrm{~km}^{2}\right)$, Kayar $\left(171 \mathrm{~km}^{2}\right)$, Joal $\left(174 \mathrm{~km}^{2}\right)$, Sangomar $\left(817 \mathrm{~km}^{2}\right)$ and Abéné $\left(119 \mathrm{~km}^{2}\right)$ (Anonymous, 2004, 2002). The objective for the choice of these areas is to protect nursery and spawning areas of species with socio-economic interest and also vulnerable species. Most of these areas are located in coastal fishing areas and their implementation limits the access of local artisanal fishers to these fishing areas.

Given the importance of the exploitation of sardinella for Senegal and the potential impact of the establishment of MPAs on its sustainable development through reserve and "Spill over" effects (HarmelinVivien et al., 2008), it would be useful to estimate the potential consequences of this management policy on the fishery in the long-term. A bioeconomic model has then been developed and used to test different management scenarios to analyze the dynamics of the fishery over the long term in response to different management measures.

\section{Materials and methods}

Several data sources were used: (i) the database of the Oceanographic Research Center of Dakar Thiaroye (CRODT) already described by several authors (Barry-Gérard, 1985; Laloë, 1985; Laloë and Samba, 1990; Thiao, 2009), for landing and effort data for purse seine and encircling gillnet fishing units, as well as the ex-vessel prices of their target species; (ii) data on fixed and variable costs of fishing units were obtained from previous studies (Ba et al., 2017); and (iii) data on the sizes and positions of MPAs (Anonymous, 2004, 2014; Brochier et al., 2015). 


\begin{tabular}{|c|c|c|c|c|c|}
\hline \multirow{2}{*}{$\begin{array}{l}\text { Marine } \\
\text { Protected Areas }\end{array}$} & \multicolumn{2}{|c|}{ Land positions } & \multicolumn{2}{|c|}{ Sea Positions } & \multirow{2}{*}{ Surface } \\
\hline & Latitudes & Longitudes & Latitudes & Longitudes & \\
\hline \multirow{2}{*}{ Abéné } & $13^{\circ} 02^{\prime} .3 \mathrm{~N}$ & $16^{\circ} 44^{\prime} .5 \mathrm{~W}$ & $13^{\circ} 02^{\prime} .3 \mathrm{~N}$ & $16^{\circ} 49^{\prime} .5 \mathrm{~W}$ & \multirow{2}{*}{$119 \mathrm{~km}^{2}$} \\
\hline & $12^{\circ} 55^{\prime} .3 \mathrm{~N}$ & $16^{\circ} 45^{\prime} .3 \mathrm{~W}$ & $12^{\circ} 55^{\prime} .3 \mathrm{~N}$ & $16^{\circ} 50^{\prime} .3 \mathrm{~W}$ & \\
\hline \multirow{3}{*}{ Joal-Fadiouth } & $14^{\circ} 04^{\prime} .5 \mathrm{~N}$ & $16^{\circ} 46^{\prime} .7 \mathrm{~W}$ & $14^{\circ} 04^{\prime} .5 \mathrm{~N}$ & $16^{\circ} 51^{\prime} .7 \mathrm{~W}$ & \multirow{3}{*}{$174 \mathrm{~km}^{2}$} \\
\hline & & & & & \\
\hline & $14^{\circ} 13^{\prime} .0 \mathrm{~N}$ & $16^{\circ} 52^{\prime} .2 \mathrm{~W}$ & $14^{\circ} 13^{\prime} .0 \mathrm{~N}$ & $16^{\circ} 57^{\prime} .2 \mathrm{~W}$ & \\
\hline \multirow{3}{*}{ Kayar } & $14^{\circ} 59^{\prime} .1 \mathrm{~N}$ & $17^{\circ} 04^{\prime} .8 \mathrm{~W}$ & $15^{\circ} 01^{\prime} .6 \mathrm{~N}$ & $17^{\circ} 10^{\prime} .8 \mathrm{~W}$ & \multirow{3}{*}{$171 \mathrm{~km}^{2}$} \\
\hline & & & & & \\
\hline & $14^{\circ} 53^{\prime} .1 \mathrm{~N}$ & $17^{\circ} 10^{\prime} .5 \mathrm{~W}$ & $14^{\circ} 55^{\prime} .6 \mathrm{~N}$ & $17^{\circ} 16^{\prime} .5 \mathrm{~W}$ & \\
\hline \multirow{3}{*}{ Saint-Louis } & $15^{\circ} 58^{\prime} .5 \mathrm{~N}$ & $16^{\circ} 31^{\prime} .5 \mathrm{~W}$ & $15^{\circ} 58^{\prime} .5 \mathrm{~N}$ & $16^{\circ} 48^{\prime} .5 \mathrm{~W}$ & \multirow{3}{*}{$496 \mathrm{~km}^{2}$} \\
\hline & & & & & \\
\hline & $15^{\circ} 50^{\prime} .0 \mathrm{~N}$ & $16^{\circ} 31^{\prime} .5 \mathrm{~W}$ & $15^{\circ} 50^{\prime} .0 \mathrm{~N}$ & $16^{\circ} 48^{\prime} .5 \mathrm{~W}$ & \\
\hline \multirow{3}{*}{ Sangomar } & $14^{\circ} 03^{\prime} 36 \mathrm{~N}$ & $16^{\circ} 58^{\prime} 48 \mathrm{~W}$ & $14^{\circ} 03^{\prime} 36 \mathrm{~N}$ & $16^{\circ} 46^{\prime} 12 \mathrm{~W}$ & \multirow{3}{*}{$817 \mathrm{~km}^{2}$} \\
\hline & & & & & \\
\hline & $13^{\circ} 46^{\prime} 48 \mathrm{~N}$ & $16^{\circ} 58^{\prime} 48 \mathrm{~W}$ & $14^{\circ} 03^{\prime} 36 \mathrm{~N}$ & $16^{\circ} 40^{\prime} 12 \mathrm{~W}$ & \\
\hline
\end{tabular}

The positions and dimensions (Table 1; Fig. 1) of the various MPAs are derived from "Decree No. 20041408 of 4 November 2004 on the creation of Marine Protected Areas" and the Management Plan for the Marine Protected Area. The area of these MPAs represents only 1\% of the Senegalese EEZ (Brochier et al., 2015). To achieve the $10 \%$ protected area of the EEZ (i.e. Aichi target 11) a very significant increase in the number or size of MPAs is needed.

Table 1.

The geographical positions and surface areas of the five marine protected areas located along the Senegalese coastline.

9 


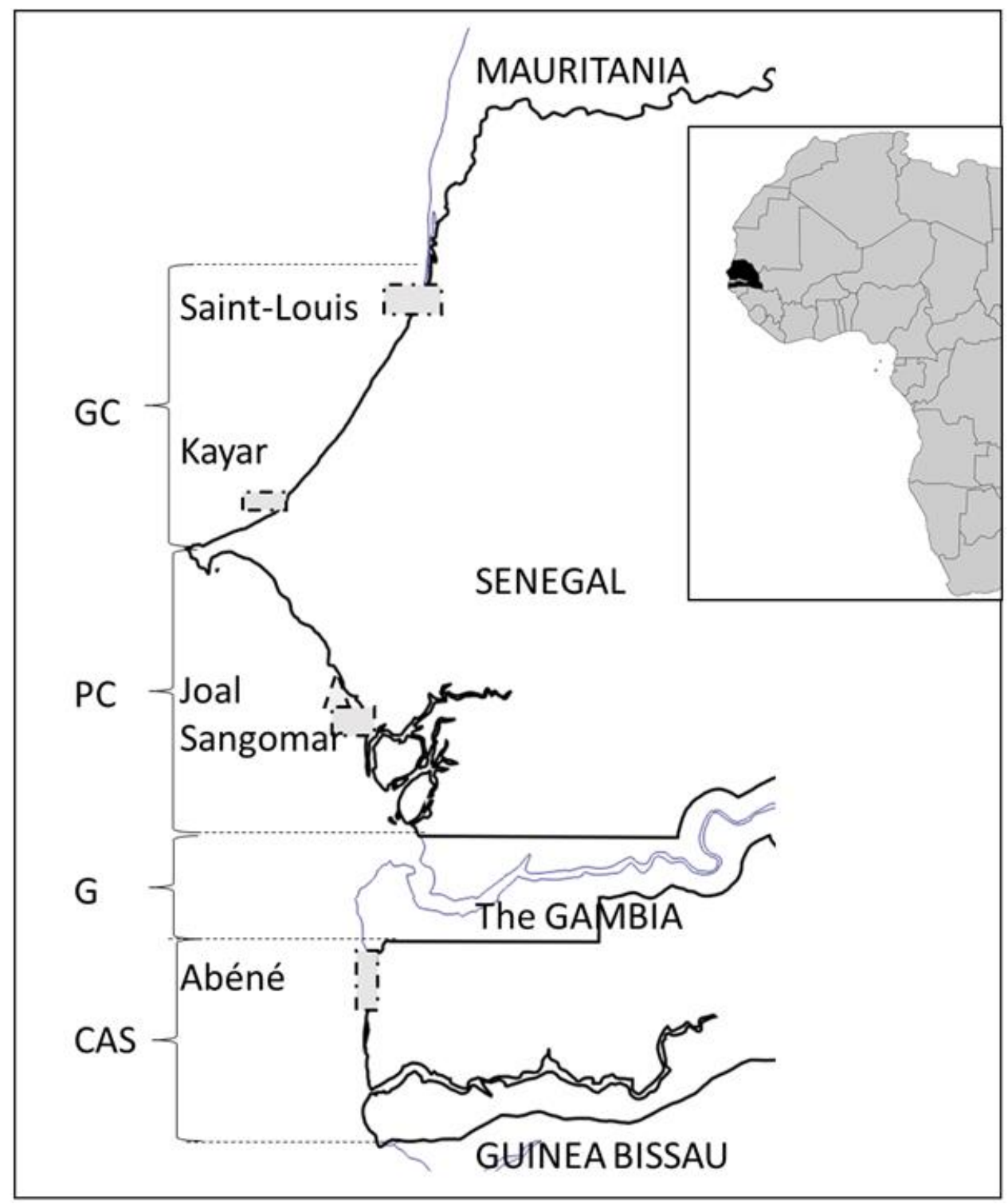

104 Figure 1: Marine protected areas (grey area in dashed line) located off the coast of Senegal. The Saint105 Louis and Kayar MPAs are on the Grande Côte (GC), the Joal and Sangomar MPAs are on the Petite Côte 106 (PC) and the Abéné MPA is located in the Casamance area (CAS). Between the PC and CAS is Gambia 107 (G) considered in the model as non-participating to the sardinella fishery. 


\subsubsection{Principle of the model}

The bioeconomic model of the small pelagic fishery proposed here is multispecies, multi-fleet and spatially explicit. The resource is composed of Sardinella aurita and S. maderensis, aggregating in large

fish schools (Brehmer et al., 2007), and the fleets targeting these schools are composed of two types of artisanal fishing units called "purse seine (PS)" and "encircling gillnets (EG)". The modeled fishing zone is the Senegalese coastal area where these fishing units operate. It is divided into Grande Côte (GC), Petite Côte (PC) and Casamance (CAS) (Fig. 1). Fishing areas outside the Senegalese EEZ, where part of the resource is seasonally present, are Mauritania (Nordex), Gambia (G) and Guinea Bissau (Sudex). The exploitation of the resource outside Senegal's waters is not explicitly modeled but determined through a fishing mortality rate defined in the initial simulation parameters. The model has monthly time steps and allows for long-term simulations (up to 40 years).

The biological component of the model is analytical, based on a simulation of monthly cohorts, the size of which depends on initial recruitment, and natural and fishing mortalities. Fishing mortality is determined by the dynamics of fishing effort, which is itself a function of past economic performance, technological change and management measures. The exogenous parameters of the model (price, costs, recruitment, growth and natural morality) are either determined before the start of the simulation or redefined during simulation as specified from a parameter file.

Fishing effort, catch and price data used for the parameterization of the model are collected using a sampling protocol, detailed in several works (Laloë and Samba, 1990; Pech et al., 2001; Thiao, 2009). The stratified random sampling has been constantly improved since the 1970s (Thiao, 2012; Thiao et al., 2012) and is conducted regularly in the main landing sites along the Senegalese coast where more than 90\% of the catches are landed. The main landing centers are: Saint-Louis, Kayar, Yoff, Soumbédioune, Hann, Mbour and Joal. The data were structured by months, landing site and fishing gear. The model is developed on the Vensim ${ }^{\circledR}$ modeling platform. 
2.1.3 A multi-species, multi-fleet and spatially explicit model

The model is an analytical age-structured, multi-cohort model. The model is inspired by the pioneering work of Thompson and Bell (Thompson and Bell, 1934), Beverton and Holt (Beverton and Holt, 1957) and Laurec and Le Guen (Laurec and Le Guen, 1981). Biological parameters for both Sardinella species were obtained from Fréon (1988) and Camarena Luhrs (1986).

Both exploited Sardinella stocks are analytically modeled with monthly cohorts and the biological part of the model is presented as "supplementary material" in annex 1.5. The fishing effort dynamics is determined through functions of outputs from the economic module. The choice of this type of model was motivated firstly by the migratory behaviors of the species and the fleets but also by the aim of testing different management scenarios such as spatial and temporal closures.

The dimensions and the parameters of the model are detailed in the supplementary material (annex 2, 3, 4).

\subsubsection{Fishing effort dynamics}

Fleets spatiotemporal dynamics is determined by the availability of the resource in time and space and endogenous economic results. Fleet dynamics is the result of different phenomena. First of all, the determination of the yearly fishing capacity, i.e. the total number of boats in the fleets and the fishing effort.

\subsubsection{Determination of the capacity of fishing}

The fishing capacity ' $U P$ ', which is constant within each annual interval is considered endogenous because of the open access characteristics of the artisanal fishery. 
155 The endogenous effort depends on the investment and the disinvestment at the end of each year.

156 Investment depends on the profit obtained during the past year. At the end of each year ' $a$ ', a fixed

157 proportion of the total profit is reinvested in the form of new fishing units ' $N U P$ ' for each fleet ' $e$ '. In the 158 case of a negative profit ' $N U P$ ' will be negative and will correspond to an exit of fishing units. The amount 159 invested ' $I V T$ ' at the end of the year is calculated as follows (equation number is set according to biologic 160 component equations presented in:

163 ' $t x i$ ' is the investment rate (reinvested positive profit share) and ' $t x i 1$ ' the disinvestment rate in case of a 164 negative profit. Given the price of a new fishing unit 'PrUP', the number of new units is then obtained 165 for each fleet ' $e$ ' and year ' $a$ ':

\subsubsection{Spatial distribution of fleets}

174 To represent the spatial redistribution of fishing units over time in Senegal, a distribution function guided

175 by the attractiveness of fishing zones is constructed. The latter is equal to the average biomass of each 
zone in relation to the total average biomass ' $B I Z S$ ' in $\mathrm{t}_{-1}$ and $\mathrm{t}_{-12}$, for each species and zone ' $z$ sen'. The average abundance of each zone is multiplied by the closure variable of zone 'Ferm' (equal to 0 when closed and to 1 when opened) so that the closed zones (MPA) (thus zero attractiveness), are not targeted by the fisheries.

$\operatorname{ATRZ}_{z s e n, t}=\frac{\sum_{i}\left[\left(\text { BIZS }_{i, z s e n, t-1}+\text { BIZS }_{i, \text { zsen }, t-12}\right) * \text { Ferm }_{z s e n, t}\right]}{\sum_{i, z s e n, t}\left[\left(\text { BIZS }_{i, z s e n, t-1}+\text { BIZS }_{i, z s e n, t-12}\right) * \text { Ferm }_{z s e n, t}\right]} \quad$ Equation 4

The fleet 'UPZ' per zone 'zsen' and fishing type ' $e$ ' can then be determined:

$U P Z_{e, z s e n, t}=U P_{e, t} \cdot A T R Z_{z s e n, t}$ Equation 5

\subsubsection{Determination of the active fleet}

A distinction is made between present fleet (fishing capacity) and active fleet ' $F l a$ ' (nominal fishing effort). To move from the first to the second, it is necessary to use the rate of activity 'txact' per fleet, determined by the short-term profitability of the activity (relative margin on the variable cost).

$F l a_{e, z s e n, t}=U P Z_{e, z s e n, t} \cdot$ txact $_{e, z \operatorname{sen}, t}$

Equation 6

2.1.5 Economic module of the bioeconomic model

\subsubsection{Fixed and variables costs}

Two types of costs are considered. The fixed costs 'CFTOT' are independent of the activity rate of the fleet but proportional to the fishing capacity (constants inputs, depreciation, maintenance of equipment and insurance). The variable costs ' $C V T O T$ ' are proportional to the active fleet but are also be related to landed quantities 
199 Where 'parCF' are the annual fixed costs per fishing unit.

200 The cost of landing, which is part of the variable costs, is proportional to the quantity of landings ' $C F T$ '.

201 'ParCV' is the amount of other variable costs per fishing unit and per month.

202

203

$\operatorname{CVTOT}_{e, z s e n, t}=$ Fla $_{e, z s e n, t} \cdot \operatorname{parCV}_{e}+C D E B_{e, z s e n, t}$

Equation 8

\subsubsection{Labor remuneration}

206

207

208

209

210

211

212

213

214

215

216

217

In the fishing sector, the remuneration of labor is generally based on a system with a "pure" or "mixed" share. The first system is the one generally observed in the Senegalese artisanal fishery. In this model, the crew remuneration 'LA' is obtained from the balance to be shared, obtained by the difference between turnover ' $R E V$ ' and variable costs ' $C V T O T$ ', and that is multiplied by the relative share going to the crew 'paramPartPa'. The annual remuneration by type of fishing ' $e$ ' is obtained from the following equation (where 'tdeba' and 'tfina' are the limits of each annual time interval 'a').

$L A_{e, a}=\sum_{t=\text { tdeb }_{a}}^{t \operatorname{fin}_{a}} \sum_{z s e n}\left(\left(R E V_{e, z s e n, t}-\operatorname{CVTOT}_{e, z s e n, t}\right) \cdot \operatorname{paramPartPa}\right) \quad$ Equation 9

with $a=a 1, a 2 \ldots, a 40$

\subsubsection{Vessel owners' profit}

The profit ' $P R O F C$ ' is the remuneration of private investors (vessel owners). It is equal to turnover $R E V$ minus the variable costs ' $C V T O T$ ' (common costs shared between crew and owner), fixed costs 'CFTOT' and labor remuneration ' $L$.' The cumulative profit per year ' $a$ ' and fleet ' $e P R O F C$ ' is obtained by summing the profit on each annual time interval: 
$\operatorname{PROFC}_{e, a}=\sum_{t=\text { tdeb }_{a}}^{t \operatorname{fin}_{a}}\left(\sum_{z s e n}\left(\operatorname{REV}_{e, z s e n, t}-\right.\right.$ CVTOT $_{e, z s e n, t}-$ CFTOT $_{e, z s e n, t}-$

222

$\left.\left.L_{e, z \operatorname{sen}, t}\right)\right) \quad$ Equation 10

223

With $\mathrm{a}=\mathrm{a} 1, \mathrm{a} 2 \ldots, \mathrm{a} 40$

224

\title{
2.1.5.4 The economic rent of the fishery
}

226

227

230

231

233

$R E N T_{e, a}=\operatorname{PROFC}_{e, a}+\left(\operatorname{RED} D_{e, a}-S U B_{e, a}\right)$

The economic 'RENT' corresponds to the private profit corrected for the net transfers between the state and the fishery (taxes ' $R E D$ ' less subsidies ' $S U B$ '). The economic rent is estimated per fleet ' $e$ ' at the end of each annual interval ' $a$ '.

The discounted economic rent 'RENTACT' is the sum of the current economic rent multiplied by the discount factor ' $F A C T$ ', obtained from the annual discount rate 'TxActu'.

$$
F A C T_{a}=\frac{1}{(1+T x A c t u)^{a}}
$$

Equation 12

$$
R E N T A C T=\sum_{a}\left(\sum_{e} R E N T_{e, a} \cdot F A C T_{a}\right)
$$

\author{
Equation 13
}

\subsubsection{Added value}

Gross added value $(G V A)$ is the difference between the value of landings and intermediate consumption inputs (all goods and services used during the production process). Net value added (NVA) is equal to gross value added less depreciation 'ParAmt' and subsidies ' $S U B$ '. It is also equal to the sum of the net remuneration of production factors (private profit and labor remuneration) plus the net income of the 
State. Gross added value is an indicator of wealth creation by the fishery (contribution to the national

243 Gross Domestic Product). Unlike rent, it integrates labor remuneration, an important element for poverty

244 reduction, which is part of Senegal's fisheries management objectives (Anonymous, 2002). If the focus of

245 the management of the small scale sector is the social dimension then value added seems to be a more

246 relevant objective than economic rent.

247 The actual net value added, which can be considered, in a similar way to the actual rent, as an objective

248 function (to be maximized) in long-term management, is obtained by using the actual factor FACT:

$V A N A C T=\sum_{a}\left(\sum_{e}\left(\sum_{t=\text { tdeb }_{a}}^{\text {fin }_{a}}\left(V A B_{e, t}-\operatorname{ParAmt}_{e}\right)-S U B_{e, a}\right) \cdot F A C T_{a}\right)$

Equation 14

\subsection{Management scenarios}

252 As a first step, the dynamics of the Sardinella fishery has been simulated over forty years, using parameters

253 based on the current fishery situation, to test the consequences of a long-term status quo on it. As a second 254 step, the response of the fishery to an increase of fishing capacity (using a fishing capacity multiplier) has

255 been simulated to determine economic and biological optima. Then, the dynamics of the fishery is 256 simulated according to different closures options (size of the MPAs) in the current situation management 257 scenario and in an overexploitation scenario 
259 The dynamics of biomass, active fleets, rent, total cost, income, profit, net added value and labor income

260 are used to compare different scenarios. The economic results are evaluated over the long term (40 years)

261 on the basis of their final discounted value (at a discount rate of 5\%).

2623.1 Consequence of a 40-year status quo on Sardinella fishery in Senegal

263 This scenario is used to show the dynamics of the fishery if current conditions, including free access to

264 the resource and subsidies of fishery, were maintained over the next forty years.

266 3.1.1 Effect of the status quo: on the biomass and the active fleet

267 After an initial small increase, the biomass is decreasing over the simulation period, and at the end of the

268 simulation $68 \%$ of the biomass is lost (Fig. 2). This decline is faster during the first 20 years, with a $60 \%$

269 biomass decrease. This is mainly due to the increase of the artisanal fleet capacity (Fig. 3). The number

270 of purse seine fishing units is doubling over the total simulation period. For encircling gillnet fishing units,

271 we observe a decrease in their activity over time and their number is divided by more than six at the

272 simulation end. 


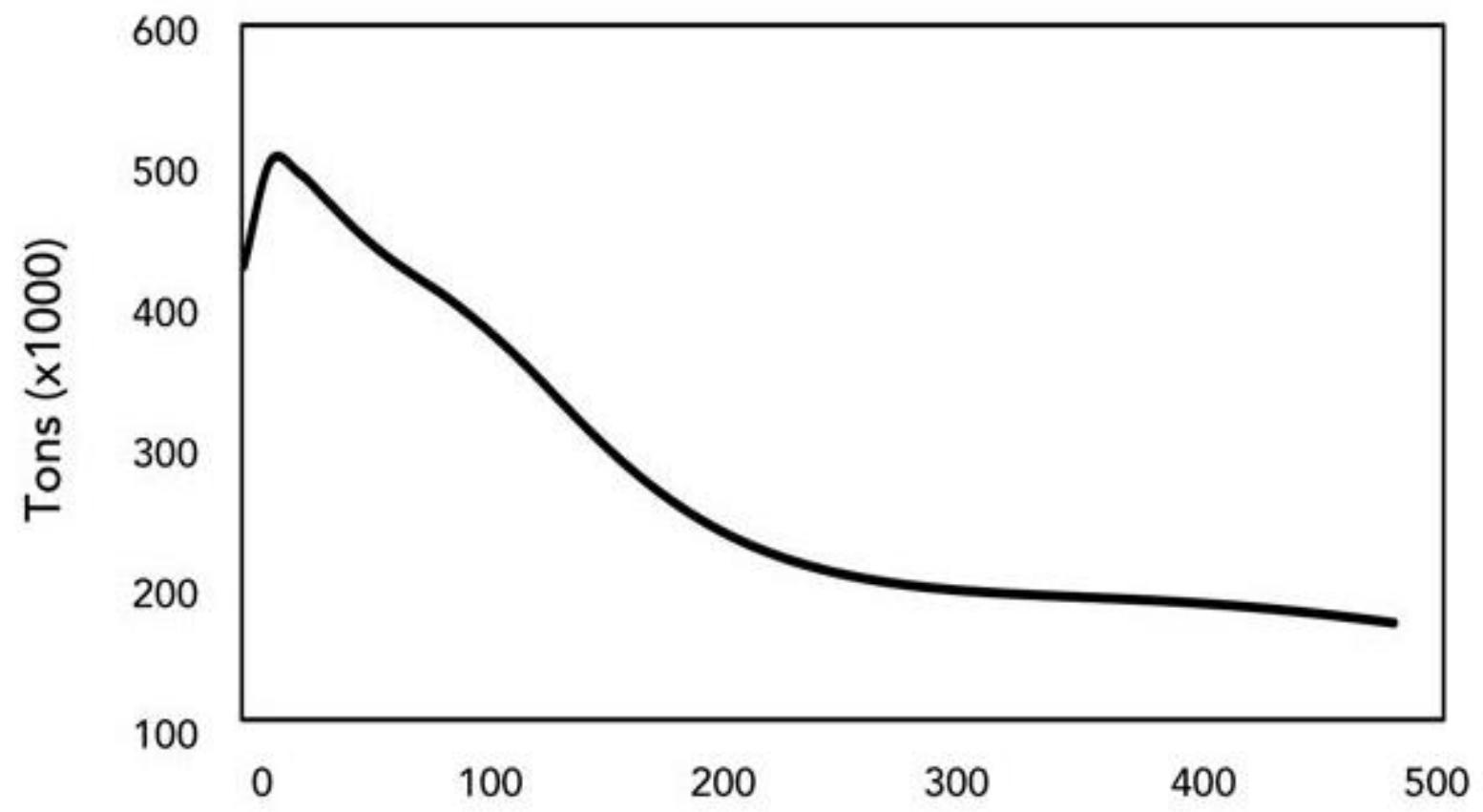

274

275 Figure 2: Dynamics of the total biomass of sardinella over the forty years according to the reference 276 situation.

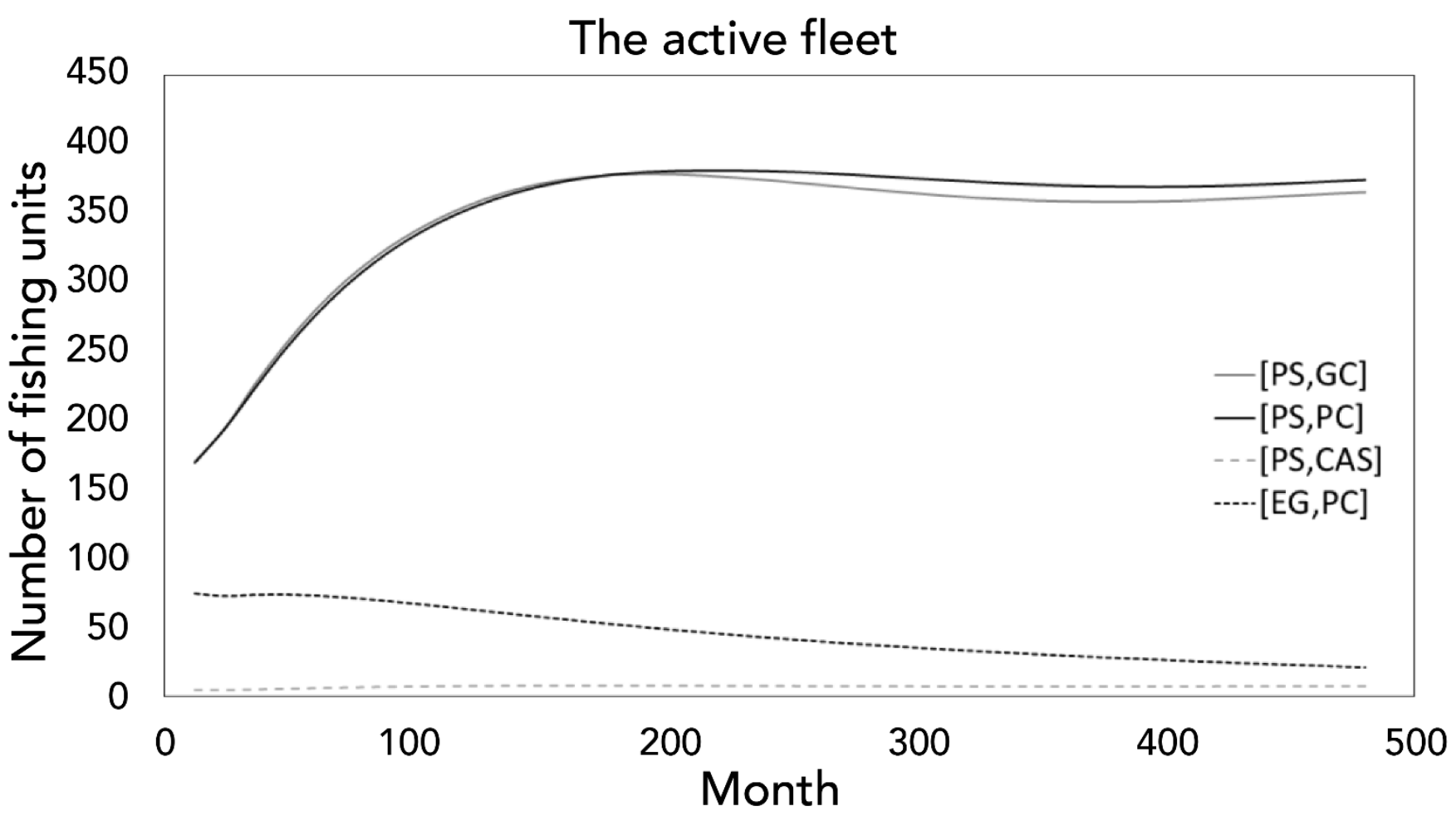


Figure 3: Dynamics of the Senegalese active fleets in the different zones. Black curve = Purse seine (PS) on the Grande Côte (GC); gray curve = Purse seine on the Petit Côte (PC); dotted gray = Purse seine in Casamance $(C A S)$; dotted black = Encircling gillnets $(E G)$ on the Petite Côte $(P C)$.

\subsubsection{Response of economic indicators to different levels of fishing capacity}

Different fishing capacity scenarios were explored, with different initial fishing capacity (using a multiplier), and taking this values constant until simulation end. A multiplier value equal to 1 corresponds to the fishing capacity level in 2013, i.e., 593 purse seine and 128 encircling gillnets fishing units. The discounted values, over the entire simulation period, for the main economic indicators were obtained as a function of the fishing capacity multiplier in order to determine the different optima according to this control variable.

The discounted income obtained in the reference scenario (i.e. for a fishing capacity multiplier equal to 1) is equal to 722 billion FCFA, corresponding to an annual catch level of 313200 tons. This is clearly less than the achievable maximum (758 billion FCFA) corresponding to a capacity multiplier equal to 1.4 (Fig. 4). In the current fishing capacity situation, the fishery does not reach its maximum sustainable yield (MSY) and is not be biologically overexploited.

In the same simulation (fishing capacity multiplier equal to1) for economic rent, profit and net value added (NVA), the fishery is not in a state of total dissipation of economic wealth (i.e. these indicators still stay positive). The profit equal zero when the capacity multiplier is set to 1.85 , and the 'NVA' equal zero when the capacity multiplier equals to 1.9 . 


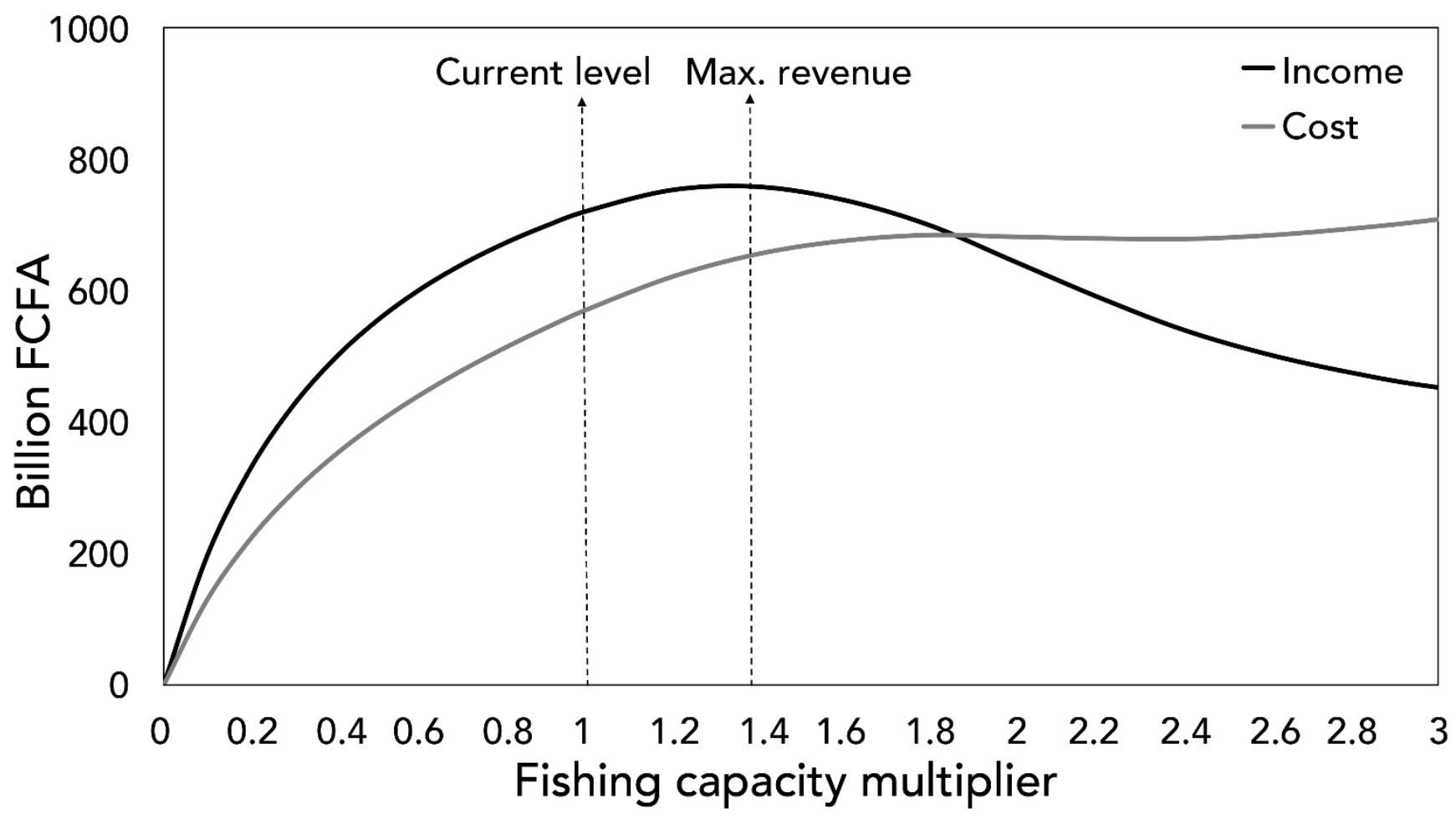

Figure 4: Responses of cost (gray curve) and income (black curve) to different fishing capacity multiplier values

To achieve the level of fishing capacity corresponding to the maximum profit (162 billion FCFA) the current effort has to be decreased by $30 \%$. However, the discounted profit still remains positive (150 billion FCFA) for the current fishing capacity level. An open access equilibrium leading to zero profit is therefore not yet reached.

However, the fishery is currently economically overexploited. The discounted rent (100.5 billion) is lower than the discounted maximum economic yield (MEY) (131.4 billion FCFA), obtained for a fishing capacity equal to the half of the reference capacity level (Fig. 5). The contribution of the fishery to the national economy, the net added value (NAV), achieves its maximum (381.7 billion FCFA) when the fishing capacity is decreased by $30 \%$. (Fig. 5). 


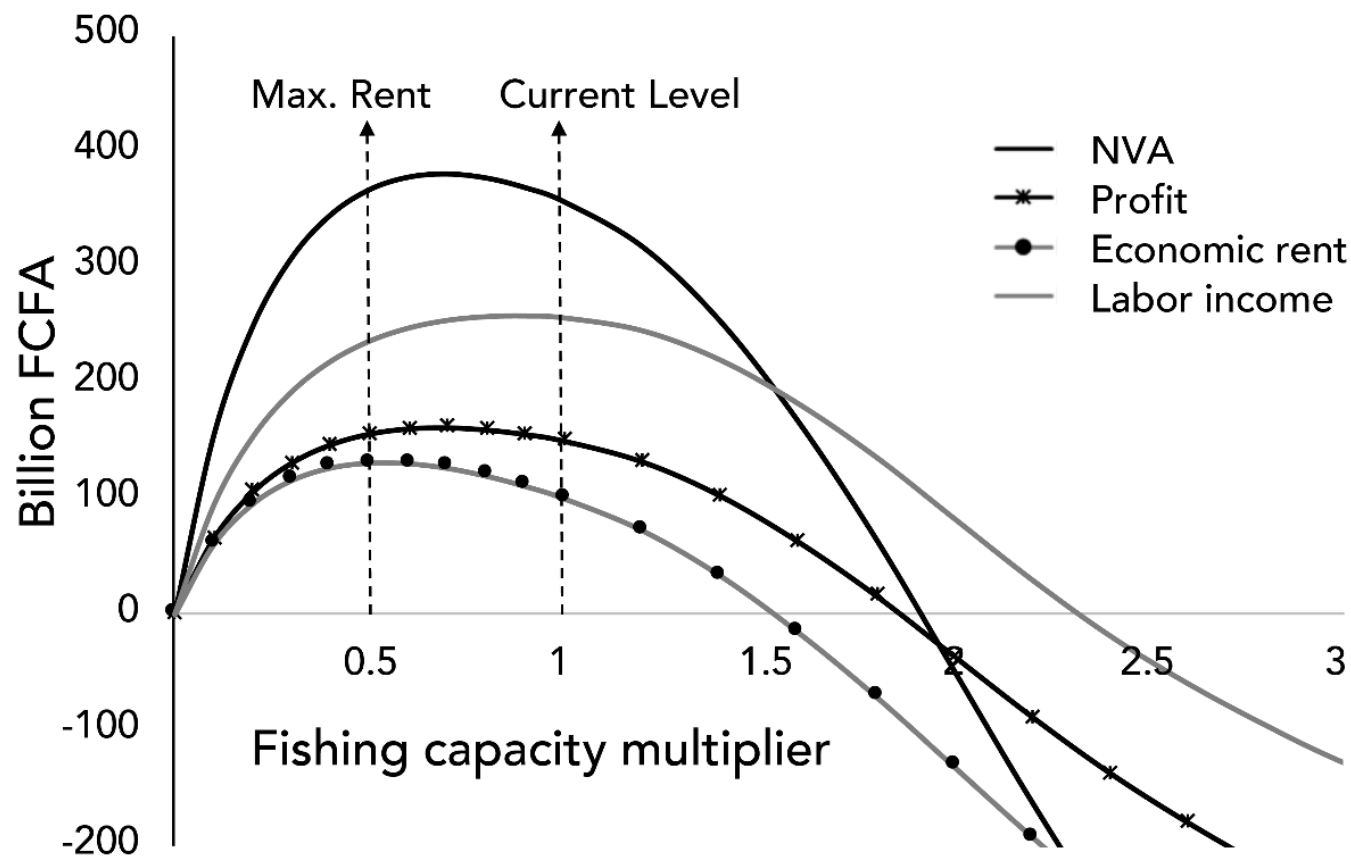

Figure 5: Responses of the main economic indicators to the increase of fishing capacity. Black curve: NVA (Net value added); gray curve: labor income; black curve with cross: profit; gray curve with circle: economic rent.

The discounted labor income (wages of crew members) is maximized with a $10 \%$ reduction in fishing capacity (Fig. 5). Thus, if the objective is to guarantee maximal remuneration for fishermen, fishing capacity should thus only be reduced by $10 \%$, still ensuring a positive, but sub-optimal profit for vessel owners. This situation, however, is not optimal for the whole national economy due to a government revenue loss equal to 50 billion FCFA. On the other hand, if one seeks to maximize the contribution of the sector to the national wealth $\mathrm{r}$ (discounted NPV), it is necessary to reduce the fishing capacity by $30 \%$.

323 Finally, if the objective is to guarantee maximum remuneration for private investors (vessel owners) a same reduction of $30 \%$ would fulfil this objective. 
In the current fishery (including open access in the fishery), closure rates of $10 \%, 20 \%$ and $30 \%$ for all fishing areas lead to an insignificant increase in final total biomass of $1 \%$. A closure of $30 \%$ of the Petite Côte alone, does not lead to an increase in total biomass (Fig. 6a, b, and c).

For discounted economic rent, closure rates of 10\%, $20 \%$ and $30 \%$ of all fishing zones result in an increase of $10 \%, 21 \%$ and $35 \%$, respectively. The closure of $30 \%$ of the Petite Côte only leads to $18 \%$ increase in economic rent (Fig. 6a, b, and c).

Concerning labor income, closures of $10 \%, 20 \%$ and $30 \%$ of all fishing areas result in increases of $10 \%$, $22 \%$ and $36 \%$ respectively. The closure of $30 \%$ of the Petite Côte only leads to an increase in labor income equivalent to that of a closure of $26 \%$ of all fishing areas (Fig. 6a, b, and c).

With overcapacity in the fishery (current fishing capacity multiplied by three), closure rates of 10\%, 20\% and $30 \%$ respectively lead to an increase of $3 \%, 7 \%$ and $9 \%$ at the end of the simulation period compared to the reference biomass (capacity multiplier equal to 1) (Fig. 6d, e, and f)). An implementation of marine reserves of $30 \%$ of the Petit Côte leads to a $5 \%$ increase in biomass. In addition, the trajectory taken by biomass in both cases (overcapacity and current situation) shows that the establishment of MPAs produces a slight reserve effect in the case of Sardinella exploitation.

In the context of an overexploitation, closures of fishing areas lead to an increase in discounted economic rent (Fig. 6d, e, and f). The closures of 10\%, 20\% and 30\% of all fishing zones result in increases of $6 \%$, $13 \%$ and $21 \%$ of discounted rent, respectively. A closure of $30 \%$ of the Petit Côte alone leads to an $11 \%$ increase.

The closure of fishing areas leads to a sharp increase in discounted labor income under overexploitation (Fig. 6d, e, and f). Closures of 10\%, 20\% and 30\% of all fishing areas lead to a 53\%, 119\% and 199\% increase in discounted labor income, respectively. A reserve of $30 \%$ of the Petit Côte allows a $104 \%$ increase. 

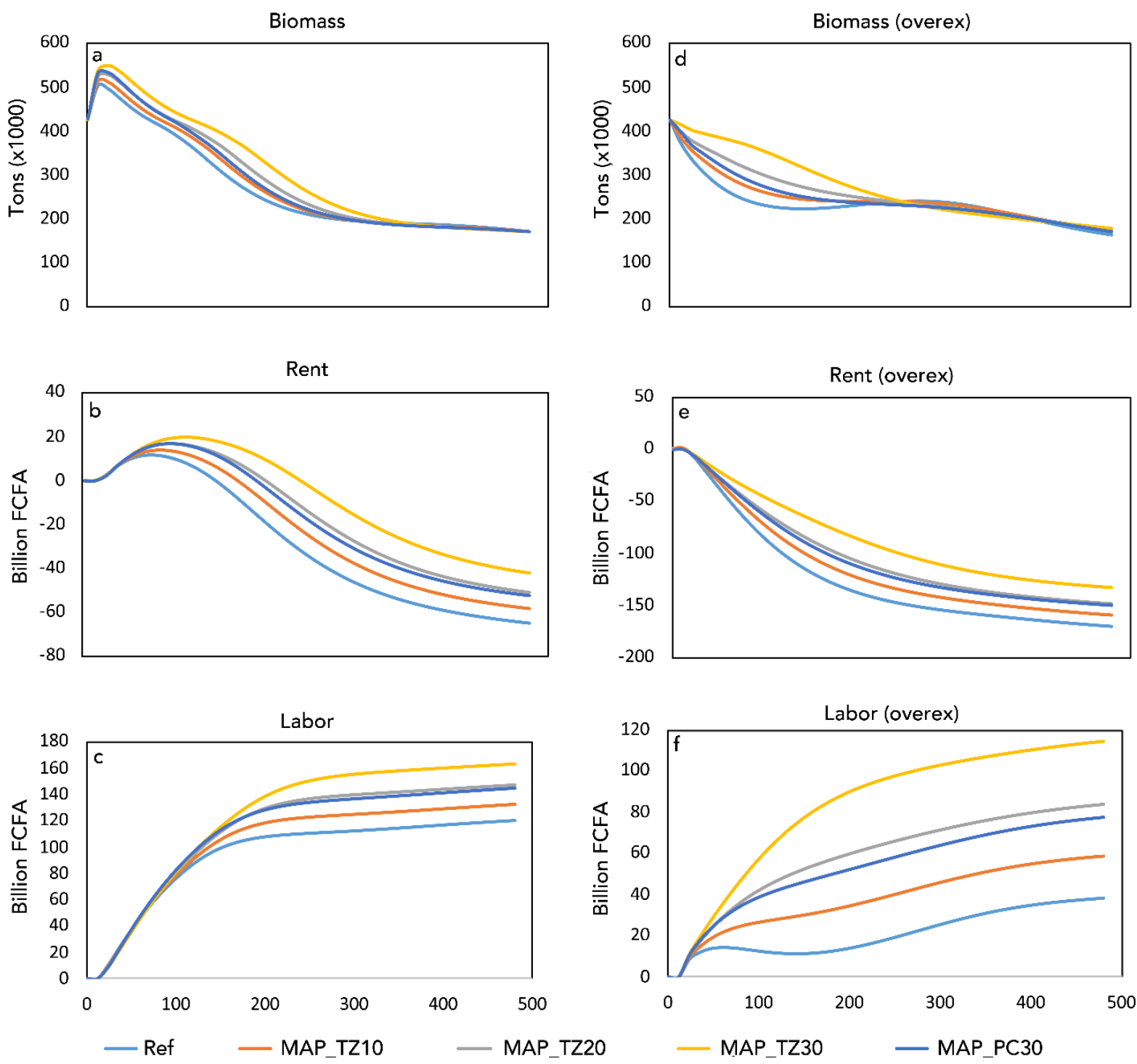

Figure 6: Responses of the biological and economic indicators of the sardinella fishery to closure rates in

352 the current exploitation context (a, b, and c) and in a context of overexploitation of the resource (d, e, and f). 'Ref' = current state; 'MPA_TZ' = Closure all zones (PC, GC, CAS); 'MPA_PC' = Closure 'Petite 354 Côte' only; 10\%, 20\%, 30\% = closing rates of fishing areas. 'Overex' (overexploited), 'TZ' (All Zones),

355 'GC' (Grande Côte), 'PC' (Petite Côte), 'CAS' (Casamance), 'G' (Gambia) and 'MPA' (Marine Protected Area). The abscissas are in months. 


\section{Discussion}

\subsection{On the state of the Sardinella fishery in Senegal}

The analysis of the reference scenario shows that the Sardinella fishery is currently economically overexploited. Compared to the optimal situation, the society loses about 11.6 billion FCFA over 40 years, or 290 million FCFA per year. This is mainly due to the open access regime leading to fleet overcapacity, i.e the capital required to optimize economic indicators, with the exception of labor income, is largely exceeded in the Senegalese Sardinella fishery. These results are consistent with the findings of several authors (Pech et al., 2001; Greboval and Catanzano, 2005; Pauly, 2006, 2007; Teh and Sumaila, 2007; Thiao et al., 2012) which show how open access or chronic subsidies lead to overcapacity, economic losses and a reduction in the exploited natural capital.

This overcapacity was also empirically confirmed by the emigration of purse seine fishing units from Senegal to Mauritania (Corten et al., 2012), in search of more profitable fishing grounds. These migrations were legally permitted through a bilateral fishing agreement (400 fishing licenses for Senegalese purse seine units) between Senegal and Mauritania. This agreement allowed purse seine fishing units to follow the natural migration of sardinella but also contributed to the reduction of overcapacity in Senegalese waters. This fishing agreement was not renewed in 2017 , so the Senegalese fishing units returned to Senegal, then increasing overcapacity again.

Sardinella catch has not yet reached the maximum sustainable yield (MSY) and thus can still be increased. But an increase in fishing effort will also be accompanied by an increase in costs difficult to sustain by the artisanal fishery. These findings suggest that the fishery is not biologically overexploited, being in contradiction with the assessments made by CECAF (Fishery Committee for the Eastern Central Atlantic) between 2001 and 2015 (FAO, 2001, 2015).

This difference in results could be explained by several factors including the assessment method used, the spatial coverage of the model and the difficulty of having heterogeneous data in the countries sharing the 
sardinella stocks. Indeed, the CECAF estimates consider the sardinella stocks from Mauritania to Senegal whereas the model utilized in this study uses only the data available in the Senegalese economic exclusive zone. CECAF also uses a global Gordon-Schaefer model over the entire Senegal-Mauritanian zone, while an analytical model applied on the Senegalese zone is used in this study. However, the scenarios carried out in this study are likely optimistic scenarios, i.e. underestimating effort and harvest, as they did not consider the possibility of an increase in fishing effort in the neighboring countries of Senegal.

\subsection{The effect of MPAs on the sardinella fishery}

Most studies address the behavior of fishing effort and abundance in pelagic and mobile species (Mesnildrey et al., 2013). This study does not only address these aspects, but also shows the economic efficiency that could be achieved by establishing spatiotemporal closures in an open access small pelagic fishery.

In the current state of the fishery, closures lead to a slight increase in biomass and economic gains in rent and labor income. These results are mainly due to the current overcapacity in the fishery. Indeed, the closure of fishing areas indirectly leads to the decline of fishing capacity in closed areas. In the case of the closure of a single fishing zone, this policy results in a displacement of the fishing capacity into areas open to fishing and subsequently to poor biological and economic results.

This particularity is essentially linked to the very high mobility of the resource and the fleet. The effect of the MPA on the fishing capacity in a single fishing zone is therefore limited by the mobile nature of the resource and the fleet. This consequence of a closure has also been shown in other fisheries (Hilborn et al., 2004; Garcia et al., 2013; Lehuta et al., 2013; Mesnildrey et al., 2013; Ba, 2017). In order to have a positive effect on both biomass and economic indicators, MPAs should be combined with a limitation of fishing effort, which is not yet the case in Senegal (Ba, 2017). In a more in-depth framework, it appears that the effects of spatiotemporal closures on the resource and on economic indicators are more evident 
when fishing is in a state of overexploitation. In this case a reduction in effort or fishing capacity can contribute to the increase in total biomass but also an improvement in economic indicators.

In line with target 11 of the Aichi Convention which suggests a closure of $10 \%$ of the coastal zone, the model shows that this objective leads to a slight increase in the total biomass of sardinella. Under the assumption of full or overexploitation, this closure rate would lead to an increase in biomass and economic gains. Given that the Sardinella fishery is economically overexploited, any closure of the area necessarily leads to a decline in fishing capacity and therefore an improvement in biological and economic indicators.

One caveat is that in these scenarios, no illegal fishing is assumed to happen in the regulated or protected marine areas. In Senegal since the beginning of the 2000s, several MPAs have been created (e.g., Kayar on the Grande Côte and Joal on the Petite Côte), but without clear effect on the dynamics of the fleet. The number of fishing units, especially purse seine, has not declined in these areas and thus these MPAs seem to be not very effective because of the high mobility of the resources and wide distribution of fishing units. Illegal, unreported and unregulated fishing "IUU" is not considered in this study even though a significant activity in the West African region could be assumed, with a high number of foreign industrial vessels operating in Senegal, neighboring countries and the region in general. Their inclusion in the model will likely increase the assessment of overcapacity of the fisheries. Therefore, we can assume that the results on overcapacity are an underestimation and recommendations regarding the overcapacity are reinforced.

The observation of the weak effect of MPA on the small pelagic fishery in Joal is in agreement with Hilborn and al. (Hilborn et al., 2004) who argue that marine reserves provide few advantages over conventional fishing management tools for fisheries that target a single highly mobile species with little or no by catch. This low impact of MPAs in small pelagic fisheries has also been reported in the pelagic 
fishery of the Bay of Biscay (Lehuta, 2010; Lehuta et al., 2013). In addition, the closure zone must be

431

432

433

434

435

436

437

large enough to protect breeding stocks of mobile species and to have spillover effects (Hannesson, 1998).

In our case, the number and size of closed areas (MPA size) seems enough to provide positive results on biomass. The results are better than those of the status quo but this difference is explained by the fact that in the model, the fishing ban is completely enforced in the closed zone. The increase in fishing costs due to the establishment of MPAs reported by several authors (Hilborn et al., 2004; Boncoeur, 2005; Mesnildrey et al., 2013; Chaboud, 2014) is less obvious in this fishery due to the seasonal migration of fishers and especially because they can change their home port.

Another point is the cost of implementation and monitoring which can be quite high for large MPAs. This cost should have been taken in account to estimate the economic return obtained for the national economy. Due to the absence of data on these MPAs costs, there were not included in our model. Then effective returns to national economy should be slightly less than those obtained in simulations.

\section{Conclusion}

The available scientific knowledge on the Senegalese artisanal fishery for small pelagic fish has allowed to build a bio-economic model, and to simulate its dynamics over several decades and then to test the impact of different spatial closure options on biological and also economic indicators.

Sardinella fishery is, from an economic point of view, overexploited in Senegal. To reach an optimal level of exploitation, it would be necessary to significantly reduce the fishing capacity. However, this solution remains difficult to implement because it requires fishermen acceptance and compensation for those who agree to leave fishery, as it is the case for fleet decommissioning plans (OECD, 2009). Moreover, the introduction of such measures will likely run up against the cultural nature of small-scale fisheries in 
Senegal, which consists mainly of family businesses in small communities where fishing plays an important identity building role.

454

The spatiotemporal closure measures lead to a decrease in capacity in closed areas. However, in the current context of open access and high sub regional mobility of resources and fleets, this measure leads to a concentration of fishing capacity and effort in areas remaining open to fishing. Thus, Senegal's compliance with target 11 of the Aichi will not have a highly significant effect on the sardinella fisheries.

For the establishment of spatiotemporal closures to have a significant impact on the fishery, closed areas should be large enough to cover an entire breeding area (Hannesson, 1998). This measure is difficult to take because the breeding areas are often very large, sometimes shared between two states and often overlay with fishing grounds. To ensure the sustainability of the exploitation of this resource, the countries concerned should have a common management plan within the maritime zones under the jurisdiction of the Sub-Regional Fisheries Commission (SRFC) member States.

In the event that a status quo situation persists, and that the States remain on unilateral or bilateral positions in the negotiations of fishing agreements and the establishment of a common concerted policy, sardinella fishery will always be subject to overexploitation and perhaps even collapse. The absence or weak coordination in the management of resources shared between the different countries will continue to lead to a "race for fish" and thus to the tragedy of common goods (Gordon, 1954; Hardin, 1968; Clark and Munro, 1975; McWhinnie, 2009). It is therefore important to remember that decision-making on this fishery must be sub-regional to be efficient because of the shared nature of the resource.

This work allows to inform decision-making in a sub-regional context by providing scenario of the impact of different regulatory scenarios, playing with the types of fishing units, considering the effort and the dynamics of the fishery in the other countries sharing the same resource. This opportunity would require the standardization of data in all countries sharing the resource. Thus, the natural perspective of our work of interest in terms of fishery management, is to extend our modeling work on the distribution area of both 
476 sardinella stocks and thus forester sub-regional collaboration providing to sub-regional and state

477 institutions a management tool built on socio-economic bases and incorporating ecological and marine

478 criteria.

479

480 Acknowledgement

481 We are thankful to the AWA project ("ecosystem Approach to the management of fisheries and marine environment

482 (EAMME) in West African waters") funded by BMBF and the IRD (grant 01DG12073E), which supported the $483 \mathrm{PhD}$ of Aliou Ba, the Preface project funded by the European Commission's Seventh Framework Program (2007484 2013) under Grant Agreement number 603521, which supported the postdoc from Aliou Ba and the JEAI LEHAO 485 as well as the AGP project ("Amelioration de la gestion des petits pélagiques en Afrique de l'Ouest" implemented 486 by 'SRFC' sub regional fisheries funded by the Mava Foundation which allowed the redaction of the paper. We are 487 thankful for the professionalism of all ISRA/CRODT technicians working all year long on the main Senegalese 488 landing sites. 


\section{REFERENCES}

491

492

493

494

495

496

497

498

499

500

501

502

503

504

505

506

507

508

509

510

511

512

513

514

515

516

517

518

519

520

521

522

523

524

525

526

527

528

529

530

531

532

533

534

535

536

537

538

Anonymous, 2014. Cinquième rapport national sur la mise en œuvre de la convention internationale sur la diversité biologique (Rapport technique). Ministère de l'Environnement et du Développement Durable, République du Sénégal, Dakar. https://www.cbd.int/doc/world/sn/sn-nr-05-fr.pdf

Anonymous, 2013. Stratégie Nationale pour les Aires Marines Protégées du Sénégal (Rapport technique). République du Sénégal, Dakar. http://extwprlegs1.fao.org/docs/pdf/sen160731.pdf

Anonymous, 2004. DECRET n² 2004-1408 du 4 novembre 2004 portant création d’Aires Marines Protégées. J. Off. Sénégal 3. http://www.jo.gouv.sn/spip.php?article6753

Anonymous, 2002. Document de Stratégie de Réduction de la Pauvreté (Rapport technique). République du Sénégal, Ministère de l'économie et des finances, Dakar.

http://www.bameinfopol.info/IMG/pdf/DSRP.pdf

Anonymous, 1992. Convention sur la Diversité Biologique (Rapport juridique). Nations Unis, Rio de Janeiro. https://www.cbd.int/doc/legal/cbd-fr.pdf

Ba, A., 2017. Analyse microéconomique et modélisation bioéconomique de la pêcherie artisanale de sardinelles au Sénégal (Thèse de doctorat en Sciences Halieutiques). Université Cheikh Anta Diop de Dakar, Dakar.

Ba, A., Schmidt, J., Dème, M., Lancker, K., Chaboud, C., Cury, P., Thiao, D., Diouf, M., Brehmer, P., 2017. Profitability and economic drivers of small pelagic fisheries in West Africa: A twenty year perspective. Mar. Policy 76, 152-158. https://doi.org/10.1016/j.marpol.2016.11.008

Barrowman, N.J., Myers, R.A., 2000. Still more spawner-recruitment curves: the hockey stick and its generalizations. Can. J. Fish. Aquat. Sci. 57, 665-676. https://doi.org/10.1139/f99-282

Barry-Gérard, M., 1985. Contribution à la connaissance de la pêche artisanale sur la Petite Côte : description et étude critique du système d'enquête à Mbour et à Joal (Document scientifique No. 137), Archive-CRODT. CRODT, Dakar.

Beverton, R.J.H., Holt, S.J., 1957. On the Dynamics of Exploited Fish Populations, Fisheries Investigation. ed. Springer Science \& Business Media, Londres, Grande Bretagne.

Boncoeur, J., 2005. Activités halieutiques et activités récréatives dans le cadre d'un espace à protéger : le cas du Parc National de la Mer d'Iroise. (Projet No. R-06-2005). UBO-CEDEM, Brest France.

Brehmer, P., Gerlotto, F., Laurent, C., Cotel, P., Achury, A., Samb, B., 2007. Schooling behaviour of small pelagic fish: phenotypic expression of independent stimuli. Mar. Ecol. Prog. Ser. 334, 263-272.

Brochier, T., Auger, P., Thiam, N., Sow, M., Diouf, S., Sloterdijk, H., Brehmer, P., 2015. Implementation of artificial habitats: Inside or outside the marine protected areas? Insights from a mathematical approach. Ecol. Model. 297, 98-106. https://doi.org/10.1016/j.ecolmodel.2014.10.034

Brochier, T., Ecoutin, J.M., Morais, L.T. de, Kaplan, D.M., Lae, R., 2013. A multi-agent ecosystem model for studying changes in a tropical estuarine fish assemblage within a marine protected area. Aquat. Living Resour. 26, 147-158. https://doi.org/10.1051/alr/2012028

Camarena Luhrs, T., 1986. La croissance de Sardinella maderensis (Lowe, 1841) au Sénégal. Océan. Trop. 2.

Chaboud, C., 2014. Economie des pêches, in: Monaco, A., Prouzet, P. (Eds.), Valorisation et économie des ressources marines, Mer et Océan. ISTE, Londres, pp. 277-344.

Clark, C.W., Munro, G.R., 1975. The economics of fishing and modern capital theory: A simplified approach. J. Environ. Econ. Manag. 2, 92-106. https://doi.org/10.1016/0095-0696(75)90002-9

Corten, A., Mendy, A., Diop, H., 2012. La sardinelle d'Afrique du Nord-Ouest : Pêches, évaluation des stocks et la gestion (Rapport technique). CSRP, Dakar Sénégal.

Cury, P., 1991. Les contraintes biologiques liées à une gestion des ressources instables, in: Cury, P., Roy, C. (Eds.), Pêcheries Ouest Africaines : Variabilité, Instabilité et Changement. ORSTOM, Paris, pp. 506-518.

Dème, M., Kébé, M., 2000. Revue sectorielle de la pêche au Sénégal: aspects socio-économiques (Rapport technique). CRODT/ISRA, Dakar.

Dème, M., Thiao, D., Sow, F.N., Sarre, A., Diadhiou, H.D., 2012. Dynamique des Populations de Sardinelles en Afrique du Nord-Ouest: Contraintes environnementales, biologiques et socio-économiques. University of Rhode Island, USAID COMFISH Project, Dakar. 
Diankha, O., Ba, A., Brehmer, P., Brochier, T., Sow, B.A., Thiaw, M., Gaye, A.T., Ngom, F., Demarcq, H., 2018. Contrasted optimal environmental windows for both sardinella species in Senegalese waters. Fish. Oceanogr. 27, 351-365. https://doi.org/10.1111/fog.12257

FAO, 2017. Rapport du Groupe de travail de la FAO sur l'évaluation des petits pélagiques au large de l'Afrique nord-occidentale. Nouadhibou, Mauritanie, 22-27 mai 2017. (technique No. 1221). FAO, Nouadhibou.

FAO, 2015. Rapport de septième session du sous-comité scientifique du comité des pêches pour l'atlantique centre-Est à tenerife, Espagne, 14-16 octobre 2015 (Rapport technique No. 1128). Rome.

FAO, 2001. Rapport du Groupe de travail de la FAO sur l'évaluation des petits pélagiques au large de l'Afrique nord-occidentale. Nouadhibou, Mauritanie, 24-31 mars 2001. (Rapport technique No. 657). FAO, Nouadhibou, Mauritanie.

Fréon, P., 1988. Réponses et adaptations des stocks de cupléidés d'Afrique de l'ouest à la variabilité du milieu et de l'exploitation: analyse et réflexion à partir de l'exemple du Sénégal (Thèse de doctorat en Sciences naturelles). Université Aix-Marseille 2, Marseille, Marseille France.

Fréon, P., Stéquert, B., Boëly, T., 1978. La pêche des poissons pélagiques côtiers en Afrique de l'Ouest des îles Bissagos au Nord de la Mauritanie : description des types d'exploitation. Cah. ORSTOM Sér. Océan. 209228.

Garcia, S.M., Gascuel, D., Henichart, L.M., Boncoeur, J., Alban, F., Monbrison, D.D., 2013. Les aires marines protégées dans la gestion des pêches. (Rapport technique). CSRP, Dakar Sénégal.

Gordon, H.S., 1954. The Economic Theory of a Common-Property Resource: The Fishery. J. Polit. Econ. 62, 124142.

Greboval, D., Catanzano, J., 2005. Rapports et documents de l'atelier de réflexion sur le contrôle et la réduction des capacités de pêche en Afrique de l'Ouest (Rapport technique No. 756). FAO, Rome.

Hannesson, R., 1998. Marine Reserves: What Would They Accomplish? Mar. Resour. Econ. 13, 159-170.

Hardin, G., 1968. The Tragedy of the Commons. J. Nat. Resour. Policy Res. 1, 243-253. https://doi.org/10.1080/19390450903037302

Harmelin-Vivien, M., Le Diréach, L., Bayle-Sempere, J., Charbonnel, E., García-Charton, J.A., Ody, D., Pérez-Ruzafa, A., Reñones, O., Sánchez-Jerez, P., Valle, C., 2008. Gradients of abundance and biomass across reserve boundaries in six Mediterranean marine protected areas: Evidence of fish spillover? Biol. Conserv. 141, 1829-1839. https://doi.org/10.1016/j.biocon.2008.04.029

Hilborn, R., Stokes, K., Maguire, J.-J., Smith, T., Botsford, L.W., Mangel, M., Orensanz, J., Parma, A., Rice, J., Bell, J., Cochrane, K.L., Garcia, S., Hall, S.J., Kirkwood, G.P., Sainsbury, K., Stefansson, G., Walters, C., 2004. When can marine reserves improve fisheries management? Ocean Coast. Manag. 47, 197-205. https://doi.org/10.1016/j.ocecoaman.2004.04.001

Laloë, F., 1985. Contribution à l'étude de la variance d'estimateurs de biomasse de poissons obtenus par échointégration. Oceanogr. Trop. 20, 163-167.

Laloë, F., Samba, A., 1990. La pêche artisanale au Sénégal. Ressources et stratégies de pêche (Thèse de doctorat en Sciences de la Vie). Université de Paris Sud (Orsay), Paris.

Laurec, A., Le Guen, J.-C., 1981. Dynamique des populations marines exploitées. Tome 1. Concepts et méthodes (Rapport scientifique et technique No. 45-1981). CNEXO/Centre Océanologique de Bretagne, Brest, France.

Lehuta, S., 2010. Impact des mesures de gestion sur la dynamique de la pêcherie pélagique du golfe de Gascogne : Quelles certitudes ? Quels descripteurs ? (Thèse de doctorat en Sciences Halieutiques). Université Européenne de Bretagne, Agrocampus-ouest.

Lehuta, S., Mahévas, S., Le Floc'h, P., Petitgas, P., 2013. A simulation-based approach to assess sensitivity and robustness of fisheries management indicators for the pelagic fishery in the Bay of Biscay. Can. J. Fish. Aquat. Sci. 70, 1741-1756. https://doi.org/10.1139/cjfas-2013-0066

McWhinnie, S.F., 2009. The tragedy of the commons in international fisheries: An empirical examination. J. Environ. Econ. Manag. 57, 321-333. https://doi.org/10.1016/j.jeem.2008.07.008

Mesnildrey, L., Gascuel, D., Pape, O.L., 2013. Integrating Marine Protected Areas in fisheries management systems: some criteria for ecological efficiency. Aquat. Living Resour. 26, 159-170. https://doi.org/10.1051/alr/2013056 
OECD, 2009. Réduction de la capacité de pêche Bonnes pratiques en matière de plans de sortie de flotte: Bonnes pratiques en matière de plans de sortie de flotte. OECD Publishing.

Pauly, D., 2007. Small but mighty: elevate the role of small-scale fishers in the world market. Conserv. Mag. 8, 24.

Pauly, D., 2006. Major trends in small-scale fisheries, with emphasis on developing countries and some applications for the social sciences. Marit. Stud. 4, 7-22.

Pech, N., Samba, A., Drapeau, L., Sabatier, R., Laloë, F., 2001. Fitting a model of flexible multifleet-multispecies fisheries to Senegalese artisanal fishery data. Aquat. Living Resour. 14, 81-98. https://doi.org/10.1016/S0990-7440(01)01108-1

Sadio, O., Simier, M., Ecoutin, J.-M., Raffray, J., Laë, R., Tito de Morais, L., 2015. Effect of a marine protected area on tropical estuarine fish assemblages: Comparison between protected and unprotected sites in Senegal. Ocean Coast. Manag. 116, 257-269. https://doi.org/10.1016/j.ocecoaman.2015.08.004

Teh, L., Sumaila, U.R., 2007. Malthusian overfishing in Pulau Banggi? Mar. Policy 31, 451-457. https://doi.org/10.1016/j.marpol.2007.01.001

Thiao, D., 2012. Bioécologie et exploitation des petits pélagiques au Sénégal (Rapport CSRP). CSRP, Dakar.

Thiao, D., 2009. Un système d'indicateurs de durabilité des pêcheries côtières comme outil de gestion intégrée des ressources halieutiques sénégalaises (Thèse de doctorat en Sciences Economiques). Université de Versailles Saint-Quentin-en-Yvelines, Ecole Doctorale SOFT (Société du Futur), Sète, France.

Thiao, D., Chaboud, C., Samba, A., Laloë, F., Cury, P.M., 2012. Economic dimension of the collapse of the 'false cod' Epinephelus aeneus in a context of ineffective management of the small-scale fisheries in Senegal. Afr. J. Mar. Sci. 34, 305-311. https://doi.org/10.2989/1814232X.2012.725278

Thiaw, M., Auger, P.-A., Ngom, F., Brochier, T., Faye, S., Diankha, O., Brehmer, P., 2017. Effect of environmental conditions on the seasonal and inter-annual variability of small pelagic fish abundance off North-West Africa: The case of both Senegalese sardinella. Fish. Oceanogr. 26, 583-601. https://doi.org/10.1111/fog.12218

Thomas, H.L., Macsharry, B., Morgan, L., Kingston, N., Moffitt, R., Stanwell-Smith, D., Wood, L., 2014. Evaluating official marine protected area coverage for Aichi Target 11: appraising the data and methods that define our progress. Aquat. Conserv. Mar. Freshw. Ecosyst. 24, 8-23. https://doi.org/10.1002/aqc.2511

Thompson, W.F., Bell, F.H., 1934. Biological statistics of the Pacific halibut fishery (Rapport scientifique No. 8). The International Fisheries Commission, Seattle, Washington. 
623

624

625

626

627

628

629

630

631

632

633

634

635

636

637

638

639

640

641

642

643

644

645

646

647

648

Biological m
Change in th
The variable tis the
according to the tot
$N_{t+1}=N_{t} * e^{\left(-Z_{t}\right)}$
The exploited stock
initial size of a coho
the beginning of the
in the Senegal-Maur
by a reduction of th
and California sardine
To take this possib
recruitment will be
(defined as paramet
in the absence of exp
the effect of fishing
than those of the Be
study is 0.5 .
When biomass ' $B I$ '
(n)

\section{Annex 1}

Biological module of the bio-economic model Change in the number of a cohort

The variable $t$ is the time of the simulation, i.e. $t=1,2 \ldots, 480$. The abundance $\mathrm{N}$ of a cohort decreases exponentially according to the total mortality rate Z:
Equation 1a

The exploited stock for each species $i$ is composed of cohorts ' $c$ ' appearing at each simulation period $t$ (month). The initial size of a cohort $c$ in each zone $z$ is equal to the recruitment $\boldsymbol{R}_{i, c, z}$, obtained from the parameter 'ParamR' at inning of the simulation. A stock recruitment relationship has never been demonstrated for small pelagics in the Senegal-Mauritania area (Fréon et al., 1978). However, it seems likely that their recruitment may be affected by a reduction of the spawning biomass (spawners) below a critical threshold. Examples such as Peruvian anchovy and California sardine have highlighted the possibility of significant falls in biomass and recruitment (Cury, 1991).

To take this possibility into account, the threshold critical biomass 'Blimi' must first be defined, below which recruitment will be affected by a decline in biomass. The threshold of critical biomass is a proportion 'PartBv' (defined as parameter) of virgin biomass 'Bv'. The latter is considered here as a parameter, estimated by simulation in the absence of exploitation of the two sardinella species. The "hockey stick" model is used to take into account the effect of fishing on recruitment. The results of these type of models are considered biologically more plausible than those of the Beverton-Holt recruitment model (Barrowman and Myers, 2000). The value of PartBv used in this

$$
\operatorname{Blim}_{i}=B v_{i} \cdot \operatorname{PartBv_{i}}
$$

Equation 2a

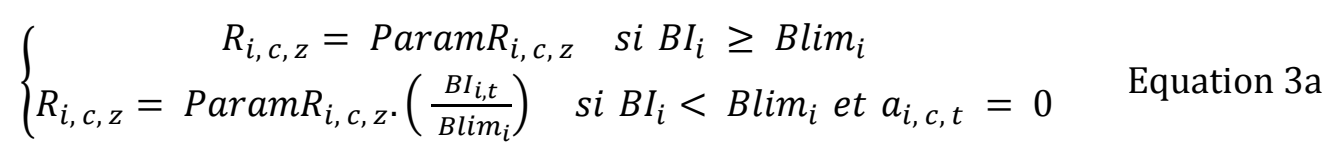


650

651

652

653

$\left\{\begin{array}{c}N_{i, c, z, t}=0 \quad t<t_{c} \\ N_{i, c, z, t}=R_{i, c, z} \quad t=\operatorname{tr}_{c} \\ N_{i, c, z, t}=N_{i, c, z, t-1}-D_{i, c, z, t-1}+M_{i, c, z, t-1}-X_{i, c, z, t-1} \quad t>\operatorname{tr}_{c}\end{array} \quad\right.$ Equation 4a
654

655

656

657

658

659

660

661

662

663

664

665

666

667

668

669

670

$\left\{\begin{array}{l}F_{i, z s e n, t}=\sum_{e} F f_{i, e, z s e n, t} \quad z \in\{G C, P C, C A S\} \\ F_{i, z, t}=\sum_{e} F f i x_{z} \quad z \in\{\text { Nordext }, G, \text { Sudext }\}\end{array}\right.$

Équation 7a

671

672 Fishing mortality per fleet is the product of the active fleet Fla, of the catchability $q$ and the possibility of fishing in

673 an area or not $\left(\mathrm{Ferm}_{z s e n, t}\right)$. Catchability is defined by species $\mathrm{i}$ and type of fishing e. It is also a function of the age

674 of the individuals $a_{\mathrm{i}, \mathrm{c}, \mathrm{t}}$. The parameter Ferm $_{z \operatorname{sen}, t}$ is used to indicate the closing rate of a zone.The possibility of

675 seasonal fishing closures affecting the Senegalese fishing zones is foreseen in accordance with the conservation

676 and / or storage policies of certain parts of the exploited areas. The variable Ferm is then between 0 (total closure)

677 and 1 (full opening).

678

679

$F f_{i, c, e, z, t}=F l a_{e, z, t} * q_{e, i, c, t} * F_{e r m} \operatorname{rsen}, t$

Equation 8a 
682 W The growth of individuals in each cohort is a function of their age. The individual length $L$ is calculated by means

683 of the von Bertalanffy function, $L_{i n f}$ is the asymptotic length, $k$ is the growth parameter and $t_{0}$ is the theoretical age 684 for which the length is zero.

685 The individual weight $\mathrm{W}$ is then obtained by applying a weight-length relation (parameters $\alpha$ and $\beta$ ). Growth is 686 considered to be identical for all zones:

687

688

$L_{i, t}=L_{\text {infi }} \cdot\left[1-e^{-k_{i \cdot} \cdot\left(a_{i, t}-t_{0 i}\right)}\right]$

Equation 9a

689

$W_{i, t}=\alpha_{i .} \cdot L_{i, t}^{\beta i}$

Equation 10a

690

691

692

It is then easy to calculate the total biomass per species $B I$ by summing the weight of all the individuals for every " cohort.

693

694

695

\section{Spatial aspects of the resource}

696

697

698

699

700

701

702

703

704

In order to simulate the migration of sardinella, at each time step, the stocks are redistributed between the different spatial cells (different zones) of the model. The stocks are distributed in 6 zones, including three in Senegal (GC, PC and CAS) and three outside (Nordext, G, and Sudext) (Fig. 1).

The monthly migration scheme is introduced by the parameter "ParamMigr" which indicates, by species and by month, the emigration rate of the stock present in each zone of origin "ori" to each of the possible destination zones "dest". The monthly CPUEs for each zone was used as a monthly local abundance index to inform the matrix. The use of monthly parameters requires creating a monthly variable between 1 and 12 which allows to redistribute the seasonal parameters (indexed by "nmois") within each year. The flux of monthly migrations " $F M M$ " between zones is obtained from the following equation: 
$F M M_{i, c, \text { ori,dest }, n m o i s, t}=N_{i, c, z, t}$. ParamMigr ${ }_{i, \text { ori,dest }, \text { nmois }} \quad$ if $t \geq \operatorname{tr}_{C}$

$F M M_{i, c, \text { ori,dest }, \text { nmois }, t}=0$

nmois $=$ mois 1, mois $2 \ldots$, mois 12

if $t<t r_{c}$

if mois $=1,2, \ldots, 12$

Equation 151a

707

708

709

710

711

714

715

716

717

Where $N_{i, c, z, t}$ is the size of a cohort, " ' the species and 'c' the cohort.

It is then possible to calculate the immigration and the emigration by zone (it is important to underline here that the elements of the indices ' $z$ ', 'ori' and 'dest' are the same, which makes it possible to establish a correspondence between these indices):
$X_{i, c, z}=\sum_{\text {dest }} F M M_{i, c, \text { ori, dest }}$
(nb: $z$ corresponds to ori) Equation $12 \mathrm{a}$
$M_{i, c, z}=\sum_{\text {ori }} F M M_{i, c, \text { ori, dest }}$
(nb: z corresponds to dest) Equation 13a

\section{The catch dynamics}

Catches are only calculated in areas of the Senegalese EEZ, so the 'zsen' index is used instead of ' $z$ ' (the 'zsen' elements are a subset of $z$ ). The number of deaths due to fishing is equal to the share of fishing mortality ' $F$ ' in total mortality ' $Z$ ', multiplied by the number of total deaths ' $D$ '. The instantaneous catches in weight ' $C$ ' are obtained by multiplying catches in number by weight individual ' $W$ ':

$C_{i, z \operatorname{sen}, t}=\left(\frac{F_{i, z \operatorname{sen}, t} * D_{i, z \operatorname{sen}, t} * W_{i, t}}{Z_{i, z \operatorname{sen}, t}}\right)$

Equation $14 \mathrm{a}$

The instantaneous catch by species is obtained by summing the catch $C$ by cohort and area.

The cumulative annual catch per species is obtained by summing the instantaneous catches in each of the annual time intervals.

The instantaneous catch by fleet $C F$ is calculated by multiplying the daily catch weight $C$ by the ratio of fishing mortality of each fleet $F f$ in the total fishing mortality $F$ :

$C F_{i, c, e, z s e n, t}=\left(F f_{i, c, e, z s e n} / F_{i, c, z s e n}\right) \cdot C_{i, c, z s e n, t}$

Equation 16a 
The dimensions of the model (subsripts)

\begin{tabular}{|l|c|l|}
\hline Nature & Symbol & \multicolumn{1}{|c|}{ values } \\
\hline Type of fishing & $e$ & ST, IND, FME \\
\hline Areas (total) & $z$ & Nordext, GC, PC, G, CAS, Sudext \\
\hline Areas (Sénégal) & $z s e n$ & GC, PC, CAS, CAS \\
\hline Species & $i$ & Sr ,sp \\
\hline Cohorts & $c$ & c1, c2..., c492 \\
\hline Years & $a$ & a1, a2,..., a40 \\
\hline Months of the year & $n m o i s$ & mois1, mois2,..., mois12 \\
\hline Origin area of fish migrations & ori & Nordext, GC, PC, G, CAS, Sudext \\
\hline $\begin{array}{l}\text { Destination area for fish } \\
\text { migrations }\end{array}$ & dest & Nordext, GC, PC, G, CAS, Sudext \\
\hline
\end{tabular}

733 


\begin{tabular}{|c|c|c|c|c|}
\hline Parameter & Meaning & Subscripts & Unit & $\begin{array}{l}\text { Value in the } \\
\text { reference } \\
\text { simulation }\end{array}$ \\
\hline ParamR & $\begin{array}{l}\text { Initial recruitment of a } \\
\text { monthly cohort of } \\
\text { species i, in a zone c }\end{array}$ & $\mathrm{i}, \mathrm{z}, \mathrm{c}$ & individual & $\begin{array}{l}\text { Defined in the } \\
\text { parameter file }\end{array}$ \\
\hline$t_{r}$ & $\begin{array}{l}\text { Date of recruitment of } \\
\text { cohort c }\end{array}$ & $c$ & time & \\
\hline$k$ & $\begin{array}{l}\text { Growth parameter of } \\
\text { the von Bertalanffy } \\
\text { function }\end{array}$ & $i$ & time & $\begin{array}{l}\text { S. ronde }: 0.100833 \\
\text { S. plate : } 0.040833\end{array}$ \\
\hline$t_{0}$ & $\begin{array}{l}\text { Fictitious "date of birth" } \\
\text { corresponding to the } \\
\text { time when the size } \\
\text { would be zero. }\end{array}$ & & time & $\begin{array}{l}\text { S. ronde : }-0.72 \mathrm{~S} \text {. } \\
\text { plate : }-7.08\end{array}$ \\
\hline$\alpha$ & $\begin{array}{l}\text { Parameter of the } \\
\text { weight-length } \\
\text { relationship }\end{array}$ & $i$ & & $\begin{array}{l}\text { S. ronde : } 0.006392 \\
\text { S. plate : } 0.0098535\end{array}$ \\
\hline$\beta$ & $\begin{array}{l}\text { Parameter of the } \\
\text { weight-length } \\
\text { relationship }\end{array}$ & $i$ & & $\begin{array}{l}\text { S. ronde }: 3.274 \\
\text { S. plate : } 3.1676\end{array}$ \\
\hline$t x i$ & Investment rate & $e$ & $\%$ & 0.3 \\
\hline txi1 & Disinvestment rate & $e$ & $\%$ & 0.1 \\
\hline $\operatorname{parCV}$ & Variable cost & $e$ & FCFA/month & $\begin{array}{l}\text { ST : } 3.449 \text { million } \\
\text { FCFA FME : } 1.171 \\
\text { million FCFA }\end{array}$ \\
\hline parLIC & $\begin{array}{l}\text { Amount of fishing } \\
\text { license (permit) }\end{array}$ & $e$ & FCFA / year & $\begin{array}{l}\text { ST }: 25000 \text { FCFA } \\
\text { FME }: 25000 \text { FCFA }\end{array}$ \\
\hline parCF & Fixed cost & $e$ & FCFA / year & $\begin{array}{l}\text { ST : } 372605 \text { FCFA } \\
\text { FME : } 324690 \text { FCFA }\end{array}$ \\
\hline parCDEB & Landing cost & & FCFA /t & 1000 FCFA \\
\hline Ffix & $\begin{array}{l}\text { Fishing mortality in } \\
\text { areas outside the } \\
\text { Senegalese EEZ }\end{array}$ & $\begin{array}{c}z \in \\
\{\text { Nordext } \\
G, \text { Sudext }\end{array}$ & & $\begin{array}{l}0.08 ; 0 . .08 ; \\
0.08\end{array}$ \\
\hline TxActu & Discount rate & & $\%$ & 5 \\
\hline$P R$ & Price per species & $i$ & FCFA /t & $\begin{array}{l}\text { Sr : } 130995 \text { FCFA } \\
\text { Sp : } 103670 \text { FCFA }\end{array}$ \\
\hline ParCiF & $\begin{array}{l}\text { Fixed intermediate } \\
\text { consumption }\end{array}$ & $e$ & FCFA/month & $\begin{array}{l}\text { ST : } 126573 \text { FCFA } \\
\text { FME : } 153207 \text { FCFA }\end{array}$ \\
\hline ParCiv & $\begin{array}{l}\text { Variable intermediate } \\
\text { consumption }\end{array}$ & $e$ & FCFA/month & $\begin{array}{l}\text { ST : } 3448629 \text { FCFA } \\
\text { FME : } 1170857 \text { FCFA }\end{array}$ \\
\hline Ferm & Closure of fishing areas & $z \operatorname{sen}$ & & $\begin{array}{l}\text { Defined according to } \\
\text { the scenarios }\end{array}$ \\
\hline FinalTime & $\begin{array}{l}\text { Final time of the } \\
\text { simulation }\end{array}$ & & month & 480 \\
\hline
\end{tabular}




\begin{tabular}{|l|l|l|l|l|}
\hline ParEquip & Crew size by fleet type & $e$ & person & ST : 20 : FME : 10 \\
\hline Parameter & Meaning & Symbol & Unit & $\begin{array}{l}\text { Value in the } \\
\text { reference simulation }\end{array}$ \\
\hline TxCaptAccess & Bycatch rate by value & $e$ & $\%$ & $\begin{array}{l}\text { ST }: 0.24 \text { IND : 0 FME } \\
: 0.32\end{array}$ \\
\hline TxCroisCapt & $\begin{array}{l}\text { Annual growth rate of } \\
\text { fishing power }\end{array}$ & $e$ & $\%$ & $\begin{array}{l}\text { ST }: 0.02 \text {. IND : FME : } \\
0.01\end{array}$ \\
\hline ParCicarbTTC & $\begin{array}{l}\text { Monthly consumption } \\
\text { of fuel ATI }\end{array}$ & $e$ & FCFA & $\begin{array}{l}\text { ST : 3150000 FCFA } \\
\text { FME : 1013000 FCFA }\end{array}$ \\
\hline ParCicarbHT & $\begin{array}{l}\text { Monthly consumption } \\
\text { of fuel ET }\end{array}$ & $e$ & FCFA & $\begin{array}{l}\text { ST }: 3706000 \text { FCFA } \\
\text { FME }: 1191000 \text { FCFA }\end{array}$ \\
\hline ParDetaxMot & $\begin{array}{l}\text { Annual engine tax } \\
\text { exemption, per fishing } \\
\text { unit }\end{array}$ & $e$ & FCFA & $\begin{array}{l}\text { ST : 415666 FCFA } \\
\text { FME : 268333 FCFA }\end{array}$ \\
\hline ParDetaxEng & $\begin{array}{l}\text { Annual exemption of } \\
\text { fishing gear taxes, by } \\
\text { fishing unit }\end{array}$ & $e$ & FCFA & $\begin{array}{l}\text { ST : 360000 FCFA } \\
\text { FME : 97200 FCFA }\end{array}$ \\
\hline
\end{tabular}




\begin{tabular}{|c|c|}
\hline $\begin{array}{c}\text { Fish Age } \\
\text { (month) }\end{array}$ & $\begin{array}{c}\text { Catchability } \\
\text { Sardienlla } \\
\text { aurita }\end{array}$ \\
\hline $4-6$ & $4.2247 \mathrm{E}-06$ \\
\hline $7-9$ & $1.1574 \mathrm{E}-05$ \\
\hline $10-12$ & $2.7162 \mathrm{E}-05$ \\
\hline $11-15$ & $1.5477 \mathrm{E}-05$ \\
\hline $16-18$ & $6.4401 \mathrm{E}-05$ \\
\hline $19-21$ & $5.9776 \mathrm{E}-05$ \\
\hline $22-24$ & $6.6904 \mathrm{E}-05$ \\
\hline $25-27$ & $6.1756 \mathrm{E}-05$ \\
\hline $28-30$ & $6.7922 \mathrm{E}-05$ \\
\hline $31-33$ & $4.677 \mathrm{E}-06$ \\
\hline $34-36$ & $1.9845 \mathrm{E}-06$ \\
\hline $37-39$ & $1.7133 \mathrm{E}-06$ \\
\hline$>39$ & $1.6992 \mathrm{E}-05$ \\
\hline
\end{tabular}

753

\begin{tabular}{|c|c|}
\hline $\begin{array}{c}\text { Fish Age } \\
\text { (month) }\end{array}$ & $\begin{array}{c}\text { Catchability } \\
\text { Sardinella } \\
\text { maderensis }\end{array}$ \\
\hline $7-9$ & $1.1362 \mathrm{E}-07$ \\
\hline $10-12$ & $9.9849 \mathrm{E}-07$ \\
\hline $11-15$ & $3.3935 \mathrm{E}-06$ \\
\hline $16-18$ & $1.4198 \mathrm{E}-06$ \\
\hline $19-21$ & $9.4787 \mathrm{E}-06$ \\
\hline $22-24$ & $1.1746 \mathrm{E}-05$ \\
\hline $25-27$ & $1.3759 \mathrm{E}-05$ \\
\hline $28-30$ & $7.5257 \mathrm{E}-06$ \\
\hline $31-33$ & $7.1591 \mathrm{E}-06$ \\
\hline $34-36$ & $1.4042 \mathrm{E}-05$ \\
\hline $37-39$ & $7.6991 \mathrm{E}-06$ \\
\hline $40-42$ & $7.1011 \mathrm{E}-06$ \\
\hline $43-45$ & $3.2785 \mathrm{E}-06$ \\
\hline $46-48$ & $5.1656 \mathrm{E}-06$ \\
\hline $49-51$ & $3.4174 \mathrm{E}-06$ \\
\hline$>51$ & $2.2283 \mathrm{E}-06$ \\
\hline
\end{tabular}


Monthly migration matrices for Sardinella aurita. Share of the number of fish migrating from a origin area to other areas. The diagonal of each matrix must remain equal to 0. ORI (origin), DEST Bissau) and nordex (Mauritania).

761

\section{S. aurita}

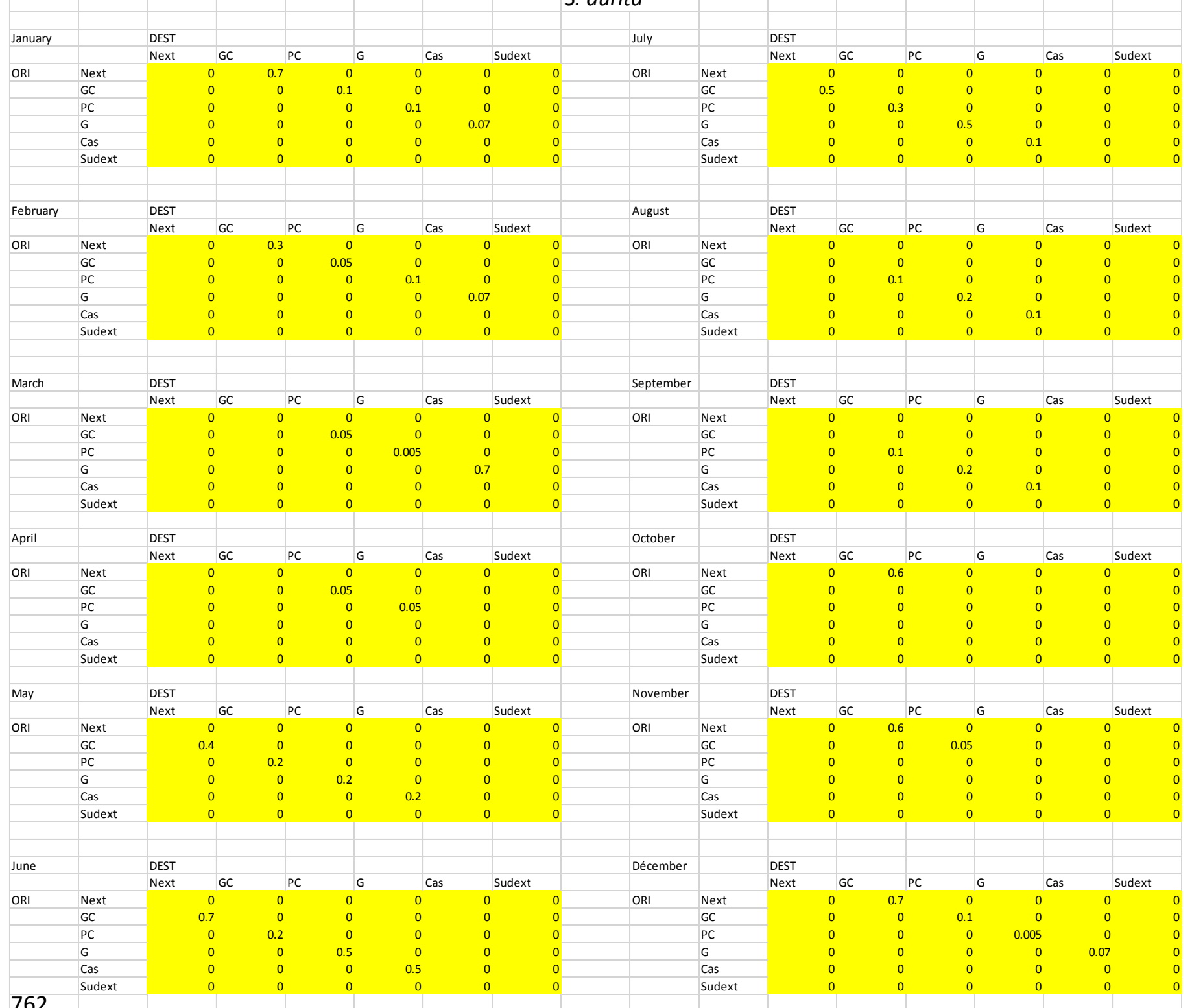

